\title{
The Impact of HR Practices on Employee Retention; A Case of BPO Sector, Sri Lanka
}

\author{
N.R.A.S.S. Wijesiri \\ Department of Business Management, Faculty of Business
}

Sri Lanka Institute of Information Technology, Malabe, Sri Lanka

\section{G.S. Paranagama}

Department of Business Management, Faculty of Business,

Sri Lanka Institute of Information Technology, Malabe, Sri Lanka

M.M.A.S. Sirirwardhana

Department of Business Management, Faculty of Business,

Sri Lanka Institute of Information Technology, Malabe, Sri Lanka

\author{
D.L.N.C. Thilakarathna
}

Department of Business Management, Faculty of Business,

Sri Lanka Institute of Information Technology, Malabe, Sri Lanka

\section{R.S Weerarathna (Corresponding Author)}

Lecturer, Department of Business Management, Faculty of Business,

Sri Lanka Institute of Information Technology, Malabe, Sri Lanka

E-mail: ranitha.w@sliit.lk

\section{U.P.G.Y Pathirana}

Academic Instructor, Department of Business Management, Faculty of Business, Sri Lanka Institute of Information Technology, Malabe, Sri Lanka

Received: Nov. 28, 2018 Accepted: Dec. 10, 2018 Online published: Dec. 11, 2018 doi:10.5296/ijhrs.v9i1.14050 URL: https://doi.org/10.5296/ijhrs.v9i1.14050 


\section{Abstract}

In today's business world, employee retention is one of the much debated topics and identifying the reasons for employee turnover and implementing the necessary policies to retain employees can be crucial. Thus, all organizations expect to minimize the employee turnover to best possible level. Therefore, the intention of this research is to study the impact of Human Resource practices on employee retention, conducted on the Business Process Outsourcing (BPO) sector in Sri Lanka. BPO sector is recognized as an emerging sector in Sri Lanka, and this sector is well known as an under-researched area. This study is significant as such research projects have been sparse in the Sri Lankan context and in order to fill that gap this research have been conducted for three companies namely Company A, B and C. The analysis was mainly based on 237 executive level employees from Company A, B and C respectively 108, 32 and 97 selected through simple random sampling. Primary data were collected using a self-administrated questionnaire and analyzed through deductive approach. According to the results obtain through regression analysis all three companies indicated that there is less impact of HR practices on employee retention. As a conclusion when management of BPO sector formulate the policies in their organizations with regard to employee retention, they should consider not only the HR practices but also, they have to concern about other factors that can effect on employees.

Keywords: retention, BPO sector, simple random sampling

\section{Background of the Study}

Due to the uncertainty of the economic environment, organizations are experiencing massive changes in the demand for the products and services they provide and are under pressure to improve performance in order to achieve organizational goals and objectives. This has increased the need for organizations to not only improve the way they deliver services, but also to examine their practices, organizational mission and goals, performance objectives, and performance measures (Begum \& Mohamed, 2016).

In today's business world, employee retention is one of the much debated topics and identifying the reasons for employee turnover and implementing the necessary policies to retain employees can be crucial. That is why a large volume of past researches has been done on this area. Retaining a large number of talented employees within an organization will provide an important source of competitive edge for an organization (Mahmood \& Zafar, 2016).

Currently most organizations compete with each other through implementing unique HRM practices and due to globalization organizations can adopt the most up-to-date HRM practices in order to accomplish organizational goals. Employing the best HRM practices is advantageous for both employee and employer, and it plays an important role in the constructive growth of the organization (Jeet \& Sayeeduzzafar, 2014). Human resource management practices mean the management of people within the internal environment of organizations, and comprises of the activities, policies, and practices involved in planning, obtaining, developing, utilizing, evaluating, maintaining, and retaining the appropriate 
numbers and skill mix of employees in order to achieve the organization's objectives.

This research is conducted on the Business Process Outsourcing (BPO) sector, which is an emerging market in Sri Lanka. Due to rapid changes in the business world and the high competition, companies tend to focus more on their core business process. Therefore, they outsource their non-core functions (Kim \& Won, 2007).

The decision by management to outsource is often made in the interest of reducing costs, reducing administration time and obtaining an advantage over competitors. Therefore, by outsourcing, companies can focus more on their core business (Silva, Udawatta.L, \& Nanayakkara, 2011).

Outsourcing to low-cost labor markets has recently become a controversial political and business topic. BPO allows businesses the opportunity to have a wide array of common corporate functions performed by third party service providers, which were previously performed and executed internally. These functions include human resources, finance and accounting, and supply-chain management (Johnson, 2005).

Human Resource Management consists of all the tasks involved in ensuring the effective and efficient use of the people inside the organization, in order to meet an organization's goals and objectives. The process of effective management of people involves cultivating effective work environments and fostering employee participation in and contribution to the organization's success (Begum \& Mohamed, 2016).

To understand the retention issues in organizations it important to explore them in detail. For that understanding, various Human Resource (HR) initiatives taken by organizations should investigated and it is important to see how these initiatives influence the retention of employees as HR policies are implemented to make employees happy and satisfied while working.

Therefore, the current study will explore the impact of HRM practices in the BPO sector in Sri Lanka. This study will also help to provide directions for future researches on the impact of HRM practices on employee retention, in the BPO sector.

\subsection{Research Problem}

Much research has been done on employee turnover and HR practices. The reason for this is that employee retention is very important in order to maintain the smooth delivery of the business process and to the long-term success of the business. It is one of the most demanding fields, because humans are very subjective. The BPO sector is also an emerging sector in Sri Lanka, and the issues related to employees in this sector are well known as an under-researched area (Wickramasinghe \& Kumara, 2010).

There were two hundred and twenty (220) BPO companies in Sri Lanka in 2014. Out of these, most (SLASSCOM, 2014). BPO companies were attached to Accounting, HR Activities, Telecommunication and Transport services (LIRNEasia, 2006). The aim of this study is to investigate the impact of Human Resource practices on employee retention in the BPO sector, by considering three companies as $\mathrm{A}, \mathrm{B}$, and $\mathrm{C}$ in the accounting field. 


\section{Macrothink}

International Journal of Human Resource Studies

ISSN 2162-3058

2019, Vol. 9, No. 1

Though there have been many research studies done in different countries in the world, such research projects have been sparse in the Sri Lankan BPO sector. According to the article LIRNEasia (2006), the only available study which analyzed this sector stated that even though employment opportunities are available in this sector, it faces difficulties in finding suitable people. Nearly about $43 \%$ of employers are dissatisfied with the supply of skilled employees (LIRNEasia, 2006). This fact reveals that there is a problem faced by employees of the BPO sector which needs to be addressed. In this article it is also shown that due to the labour intensive nature of the BPO sector the labour cost represents the highest share of the total operating costs(about $44 \%$ of the total operating costs). Therefore, organizations need to devote attention to their employees' well-being. If these employees leave, the organization has to bear a large cost, it is very important for the organization to retain its employees. To maintain, retain and manage an effective workforce, the HR practices of a company play a vital role. Thus, there seems to be a research gap in this area, a gap that can be filled by this study.

As one of the operational issues faced by the three companies the researches selected, company A faced an increased number of leavers when compared with their total number of employees, going from seventy (70) to ninety-two (92) over three years from 2015 to 2017. This is shown in the chart given below.

Table 1. Number of Leavers in Company A

\begin{tabular}{lll}
\hline Year & Total no. of employees & No. of leavers \\
\hline 2015 & 127 & 70 \\
2016 & 144 & 87 \\
2017 & 294 & 92 \\
\hline
\end{tabular}

Source: Developed by the authors

This is evidence that the impact of HR practices on employee retention in the BPO sector in Sri Lanka is an important area to be studied. Therefore, based on the facts that we have identified, the purpose of this research is to find the impact of HR practices on employee retention in the BPO sector in Sri Lanka.

\subsection{Research Question(s)}

- "Is there an impact of HR practices on employee retention in the BPO sector in Sri Lanka?"

- "What are the HR practices available in the organizations?"

- "Is there any relationship between the HRM practices and employee retention?"

- "What is the retention level of the organizations?" 


\subsection{Research Objectives}

General Objective;

To identify the impact of HR practices on employee retention in the BPO sector.

Sub Objectives;

- To study organizational HR practices.

- To measure the employee retention level of the organizations.

- To measure the relationship between HR practices and employee retention.

Contribution of the Study

This study is aimed to identify the impact of HR practices on employee retention in relating to BPO sector in Sri Lanka. The result of the study would help in developing a better understanding on how to manage the HRM practices keeping in view the dimensions of employee commitment, employee retention. This research will be a guidance tool for all the business organizations and future researchers. This will be a good learning opportunity for the researchers to expand the knowledge on conducting researches.

This study will hopefully a great help for those who are willing to do further researches on employee retention as it provides the information that fair HRM practices has greater impact on the employee retention rate and will contribute to practical problem-solving process in employee turnover reduction. The future researches can use the results of this study to make the base for future study in this area and they can carry it on broader aspects and different industries.

There are numerous benefits for the group of undergraduate researchers who get involved in this research. This research experience helped undergraduates to have a better understanding about published works, to familiarize with qualitative $\&$ quantitative data, to balance collaborative \& individual work etc.

This will also come to the use for the employers who are trying to identify the sources and initiatives of job satisfaction to retain their competitive workforce. Currently this research would be significant in diagnosing the success of HRM practices in Business Process Outsourcing companies in Sri Lanka. The study has its importance in explaining the implementation of HRM practices and their contribution towards the success keeping the employee within the organization. The study excellence lies in the facts on how to increase the employee commitment and to gain the employee loyalty by lowering the turnover rate.

\section{Literature Review}

\subsection{Human Resource Practices}

The general objective of this study is to identify the impact of HR practices for employee retention in BPO sector.HR practices which are following in organizations are strategic in nature. Those practices are providing important guidelines in order to facilitate the executive 
business plan.

Human Resource Management combines tasks that are used for efficient and effective management of employees in the organizations. Organizations are using HR practices in order to manage employees align with Human Resource Management. Many researchers have conducted studies in HR related to HR practices and they have given different definitions according to their studies.

Human Resource Practices refers to the management of people within the internal environment of organizations, comprising of activities, policies, and practices involved in planning, obtaining, developing, utilizing, evaluating, maintaining, and retaining the appropriate numbers and skill mix of employees to achieve the organization's objectives (Jeet \& Sayeeduzzafar, 2014). HR practices are designed in a way to achieve organizational goals, to have positive employer employee relationship and to create value to the organization (Marescaux, De Winne, \& Sels, 2012). Flexible and innovative HR practices are helping to gain competitive advantage through employees. After identifying these kind of factors researchers have focused their attention towards HR practices in private sector but most of them have not focus their attention towards BPO sector. Present study focuses about Recruitment and Selection, Performance management, Compensation and rewards management and Training and development which are considered as main four HR practices. Past researchers have conducted their studies in these areas.

\subsection{Recruitment and Selection}

The main objective of Recruitment and Selection is related to strategic goals of the organization is to hire the right person to the right job the in the first attempt (Roselius \& Kleiner, 2000). Recruitment and selection are linked with retention of employees and selecting the right talent is another way of reaching competitive advantage through employees and to reduce employee turnover (Kundu \& Lata, 2017). The effectiveness of recruitment practices of an organization can be measured through the extent which organization attract committed and well-qualified employees who remain with the organization for a longer period (Hughes \& Rog, 2008). The ultimate goal of recruitment is to generate qualified pool of applicants matching with job requirements (El-Kot \& Leat, 2008).

Through his past studies it shows that both recruitment and selection is affecting for retention of employees.

\subsection{Performance Management}

Performance management is ensuring achieving organizational goals in an efficient and effective manner. Performance management encompasses activities such as joint goal-setting, continuous progress review and frequent communication, feedback and coaching for improved performance, implementation of employee-development programs and rewarding achievements (Sahoo \& Mishra, 2012). Performance management must be clearly linked to the delivery of strategic priorities and the language used should be simple and understandable (Atkinson, 2012). An effective performance management system should include job description, an appropriate selection process, accomplishment-based performance standards, 
outcomes and measures, effective orientation, education and training, coaching and feedback, periodic performance-development discussions and an effective compensation and recognition system which leads to increase in productivity. There are three stages of strategic. The first stage is establishing the strategic structure of the Performance Management System. In the second stage consists of designing the reporting structure, and the third stage creating the culture needed to become a performance-driven organization (Sahoo \& Mishra, 2012). As today's business world is competitive attracting and retaining the right talented people is one of the main challenges any organization has to face. One way of the effective method to engage and commit employees towards the organization is managing employee performances. This leads to ensure that employees retain with the organization for a longer period of time (Pandita \& Ray, 2018). Therefore, these researchers shoe the importance of performance management and positive impact for retention of employee in the organization.

\subsection{Compensation and Reward Management}

Compensation and Reward can simply be explained as something which is used by employers in order to recompense their employees for a loss or to recognize their work/performance and efforts in relating to their job role (Huang \& Kleiner, 2005). This compensation can be in the form of financial or Non-financial benefits. This compensation should be aligned with organizational structure and, business strategy to achieve goals and objectives of the organization. According to Hsieh \& Kleiner (2003), a general compensation system consists of three main components including a base compensation, indirect compensation and rewarding incentives. Having an organized and transparent reward system may help to attract, engage and retain key staff of an organization which finally helps to achieve higher organizational financial performances (Lardner, 2015). Monetary and Non-monetary benefits are main concerns employees are considering when selecting an organization to work or for the retention (Coffey, 2013). Implementing good reward and compensation policies allows to retain talented employees within the organization because when employee are more satisfy with the organization they will stay in the organization for a longer time period (Chiekezie, Emejulu, \& Nwanneka, 2017).Human needs are different form one another so if organizations needs to retain their employees so in order to retain employees within the organization employers should understand them and should establish effective compensation and reward system.

\subsection{Training and Development}

Training \& development refers to a systematic development of the knowledge, skills and attitudes required by employees to perform a given task or job adequately (Olaniyan \& Ojo, 2008). Different models have developed in order to design effective training programs. Kirkpatrick level is one such model which has four main stages named as reaction, leaning, behavior and result. Training programs increase personnel efficiency, professional growth, and smooth and more effective organization's operations also the same study reveals that training plays a vital role in the success of an organization as it provides the employees an opportunity to improve their competencies (Olaniyan \& Ojo, 2008). This is affecting for retention of employees within the organization for a longer time period. 


\subsection{Retention}

Science employee retention is one of the main objectives of employee management many studies have conducted in related to employee retention. Retention is simply known as keeping employees within the organization for the maximum period. Employee retention is one of the hardest challenges any organization has to face. If employees are happy with the organization, they will remain with the organization for a longer period and will be committed towards the organization. This can have positive impacts like enhance organizational performances and increase customer satisfaction (Mathimaran \& Kumar, 2017).Staff retention will directly impact on the smooth operation, productivity, performances and long-term sustainability of any organization, and it will also indirectly an impact on the image of the company as a whole (Azeez, 2017). Also factors like Organizational fit and culture, family support, rewards, recognition, training and development and career development all plays an important role in retention. The work environment is also a key factor when it comes to the retention of employees (Irshad \& Afridi, 2011). In addition to that a study conducted in Sri Lankan higher education sector indicates that in order to have sustainable competitive advantage institutes should retain top level reputable professors which is directly linked with reputation (De Silva \& Chitraranjan, 2018)

\section{Research Methodology}

\subsection{Conceptual Framework}

The conceptual framework is developed based on the previous literature review. Human Resource (HR) practices is the independent variable and the employee retention is the dependent variable. HR practices is conceptualized under four dimensions which are recruitment \& selection, performance management, compensation \& reward management and training \& development. The employee retention is conceptualized under three dimensions which are job security, welfare management and work environment.

\section{a) Definitions of Key Dimensions}

i. HR Practices- Human Resource Practices refers to the management of people within the internal environment of organizations, comprising of activities, policies, and practices involved in planning, obtaining, developing, utilizing, evaluating, maintaining, and retaining the appropriate numbers and skill mix of employees to achieve the organization's objectives (Jeet \& Sayeeduzzafar, 2014).

a. Recruitment \& Selection- It refers as to hire the right person to the right job the first time (Roselius \& Kleiner, 2000).

b. Performance Management- Performance management encompasses activities such as joint goal-setting, continuous progress review and frequent communication, feedback and coaching for improved performance, implementation of employee-development programs and rewarding achievements (Sahoo \& Mishra, 2012). 
c. Compensation and Reward Management- It described as something which is used by employers in order to recompense their employees for a loss or to recognize their performance and efforts in relating to their job role (Huang \& Kleiner, 2005).

d. Training \& Development- It refers to a systematic development of the knowledge, skills and attitudes required by employees to perform a given task or job adequately (Olaniyan \& Ojo, 2008).

ii. Employee Retention - Retention is a highly discussed and debated topic in the Human Resource (HR) field, since retention is one of the main objectives of almost every organization. Employee retention is a process which encourages the employees to remain within the organization for maximum period or till a project is ended (Biason, 2014).

a. Job Security- "Job security creates a climate of confidence among employees which cultivates their commitment on the company's workforce" (Asiedu-Appiah, Kontor, \& Asamoah, 2013).

b. Welfare Management- Welfare defines an act of seeking physical, mental, moral and emotional well-being of an individual (Patro \& Raghunath, 2015).

c. Work Environment- Work environment refers to the physical, geographical, professional surroundings or conditions wherein employees interact with colleagues and equipment in order to carry out some specific activities (Osibanjo, Abiodun, \& Adeniji, 2014).

Below the conceptual framework was developed based on the upper said articles.

\section{Independent Variable}

\section{HR Practices}

1. Recruitment and Selection

2. Performance Management

3. Compensation and Reward Management.

4. Training \& Development

\section{Dependent Variable}

\section{Retention}

1. Job Security

2. Welfare Management

3. Work Environment

Figure 1. Conceptual Framework

b) Hypothesis

- Hypothesis 1

$\mathrm{H}_{0}$ - There is no relationship between recruitment \& selection and employee retention. 


\section{Macrothink}

International Journal of Human Resource Studies

ISSN 2162-3058 2019, Vol. 9, No. 1

$\mathrm{H}_{1}$ - There is a relationship between recruitment \& selection and employee retention

- Hypothesis 2

$\mathrm{H}_{0}$ - There is no relationship between performance management and employee retention.

$\mathrm{H}_{1}$ - There is a relationship between performance management and employee retention.

- Hypothesis 3

$\mathrm{H}_{0}$ - There is no relationship between compensation \& reward management and employee retention.

$\mathrm{H}_{1}$ - There is a relationship between compensation \& reward management and employee retention.

- Hypothesis 4

$\mathrm{H}_{0}$ - There is no relationship between training \& development and employee retention.

$\mathrm{H}_{1}$ - There is a relationship between training \& development and employee retention.

\subsection{Research Philosophy}

Research philosophy can be categorized in to positivism, realism, interpretivist, and pragmatism (Saunders, Lewis, \& Thornhill, 2009). This research is related with the positivism philosophy. Researchers identified an actual problem in the companies in Business Process Outsourcing industry and started to research on that to find solutions.

\subsection{Research Approach}

There are two main approaches for a research as inductive and deductive approaches (Saunders, Lewis, \& Thornhill, 2009). This research is relevant with the deductive approach. In this research the researchers selected a theory, i.e. employee retention which comes under the Human Capital Management. In this research the researchers were able to test the theory.

\subsection{Research Strategy}

As the study used a deductive approach, the researchers selected questionnaire and interview methods under this strategy. The interviews were conducted to fulfil the sub objective of studying organizational HR practices. The survey was used to collect the quantitative data to test the theory. This strategy is cost effective and can collect data from a wide population.

\subsection{Questionnaire Method}

Questionnaire was distributed to collect mainly the primary data for the analysis of this study. The questionnaire was designed based on the dimensions which were derived from the past literature.

i. Questionnaire Design- Questionnaire was used as the research instruments where a Likert scale questions were used as it is much easier for the respondents to answer the questions. It covered demographic factors, HR practices and the employee retention. 
c) Methods of Measurements

Each dimension was measured through a Likert scale questions in the questionnaire. There are mainly three parts in the questionnaire. The demographic factors were measured using a nominal scale. The HR practices is measured through a Likert scale under four main dimensions. The employee retention, the dependent variable was also measured using Likert scale under three main dimensions.

Purpose of the Study/ Type of the Investigation/ Study setting and Unit of Analysis

There are three types of purposes in researches. They are exploratory, descriptive, and explanatory. In this research it mainly tries see the impact as well as the relationship between the independent and the dependent variable. As this also check the casual relationship between variables this study is also represents the explanatory purpose. The explanatory purpose is mainly to see the casual relationship between variables (Sekaran, Research Methods for Business: A Skill Building Approach, 2003).

Population and Sample of the Study

The population of this study is the total number of executive employees of A, B and C companies. As cited by Sekaran and Bougie (2010) Krejcie and Morgan (1970) and Cohen (1969) stated following sample sizes should be determined by the researchers to conduct proper research.

Table 2. Sample sizes

\begin{tabular}{lcr}
\hline Company & Population & Sample Size \\
\hline A Company & 150 & 108 \\
B Company & 35 & 32 \\
C Company & 130 & 97 \\
\hline
\end{tabular}

d) Reliability of the Measures

Reliability can be defined as the degree to which your data collection techniques or analysis procedures will yield consistent findings (Saunders, Lewis, \& Thornhill, 2009). A pilot survey was conducted before conducting the survey to check the reliability of the instrument. The Cronbach's Alpha value indicates the reliability of the questionnaire.

e) Validity Test of the Measures

Validity refers to the degree to which data collection methods accurately measure what they were intended to measure (Saunders, Lewis, \& Thornhill, 2009).

\section{Data Analysis and Discussion}

\subsection{Qualitative Analysis}

The objective of studying the HR practices of the selected organizations was achieved 


\section{Macrothink Institute $^{\mathrm{TM}}$}

through interviews which were conducted with the HR managers of Company A, B and C. The collected data was analyzed through "Word Cloud" tool. The words, which are the most dominant in the responses received based on their relative size and the frequency, are taken as the most highlighted components by the managers (Bhanot, Rao, \& Deshmukh, 2016).

The HR Practices that are mainly highlighted by the statements of HR Managers are Recruitment and Selection, Training and Development, Performance Management and Compensation Management. Therefore, the researchers have selected the above practices to represent the Independent Variables; the HR Practices

\subsection{Reliability and Validity Analysis}

Reliability Testing

Reliability testing was conducted to test the internal consistence of the instrument and for that the Cronbach's Alpha values were used. The Cronbach's Alpha values are shown in below table.

Table 3. Reliability Statistics for independent \& Dependent Variables- Pilot and Main Surveys

\begin{tabular}{lcr}
\hline Dimension & Cronbach's Alpha - Main & Cronbach's Alpha - Main \\
& Survey & Survey \\
\hline Independent Variables: & & \\
Recruitment and Selection & 0.504 & 0.800 \\
Training and Development & 0.790 & 0.783 \\
Performance Management & 0.676 & 0.944 \\
Reward and Compensation & 0.672 & 0.912 \\
Career Development & 0.280 & - \\
Dependent Variables: & & \\
Job Security & 0.688 & 0.797 \\
Welfare Management & 0.719 & 0.841 \\
Work Environment & 0.583 & 0.839 \\
\hline
\end{tabular}

Source: Survey data

The closer the reliability reaches 1.0, the better the reliability (Sekaran, Research Methosds for Business: A Skill Buliding Approach, 2006). Furthermore, the reliability value less than 0.60 are considered as poor and if the value is in between 0.60 and 0.70 considered as acceptable. The highest reliability range is considered to be over 0.80 . The dimension "Career Development" was removed from the questionnaire due the poor reliability of pilot survey. According to the table, all dimensions of main survey scored more than 0.7 , which indicates a higher reliability.

\subsection{Validity Testing}

Since, all the respondents have responded for the survey the validity is shown as $100 \%$. 


\section{Macrothink

\subsection{Characteristics of the Sample}

Based on the findings it was evidenced that majority of the selected sample represented the 20 to 30 years age category. It is visible that majority of employees of all three companies have a service period of less than five years which provided an evident that there is an issue related to the retention of employees in all three companies. Gender distribution among three companies visible that except Company A, the other two companies have a higher male representation. Furthermore, in all three companies, there are employees who have completed a degree level qualification

\subsection{Analysis of Retention Level}

This analysis is conducted to measure the employee retention levels of three companies. To achieve this objective "One Sample T-Test was carried and the below mentioned scale was used to determine the level of employee retention.

- If $\mathrm{ER}<3$, then employee retention level is low

- If $\mathrm{ER}=3$, then employee retention level is moderate

- If ER>3, then employee retention level is high

Table 4. Summary of One Sample T-Test

\begin{tabular}{lcr}
\hline Company & N & Mean \\
\hline Company A & 108 & 2.95 \\
Company B & 32 & 2.76 \\
Company C & 97 & 2.55 \\
\hline
\end{tabular}

Source: Developed by the authors

According to table 4 all three companies' means values are less than three. It indicates that there is a low employee retention level in all the companies, which were selected.

\subsection{Correlation Analysis}

The coefficient donated by " $r$ " is measure of the closeness of the relationship between two variables. The "r" value lies between -1 and +1 while the degree of " $r$ " indicates the strength and the direction of the linear relationship (Saunders, Lewis, \& Thornhill, 2009). The closer the correlationis to $+/-1$, the closer to a perfect linear relationship. 
Table 5. Summary of Correlation Analysis

\begin{tabular}{llcl}
$\begin{array}{l}\text { Variable (Correlation with } \\
\text { Retention) }\end{array}$ & N & $\begin{array}{c}\text { Pearson's Correlation } \\
\text { Value with retention (r) }\end{array}$ & Sig (2- Tailed) value \\
\hline Company A & 108 & 0.063 & 0.518 \\
Recruitment \& Selection & 108 & 0.301 & 0.002 \\
Performance Management & 108 & -0.011 & 0.909 \\
Compensation \& Reward & 108 & 0.123 & 0.203 \\
Training \& Development & & & 0.055 \\
Company B & 32 & 0.343 & 0.392 \\
Recruitment \& Selection & 32 & 0.157 & 0.001 \\
Performance Management & 32 & 0.553 & 0.005 \\
Compensation \& Reward & 32 & 0.486 & \\
Training \& Development & & & 0.000 \\
Company C & 97 & 0.573 & 0.000 \\
Recruitment \& Selection & 97 & 0.482 & 0.000 \\
Performance Management & 97 & 0.588 & 0.000 \\
Compensation \& Reward & 97 & 0.622 & \\
Training \& Development & & &
\end{tabular}

There is a strong, positive and significant relationship between HR practices and retention in company C. Majority of HR practices of Company A have weak positive relationship with employee retention where compensation and reward has a negative weak relationship with the retention. In Company B, only compensation \& reward and training and development have strong, positive and significant relationship with employee retention.

\subsubsection{Regression Analysis}

Regression analysis is used to see the impact of HR practices on employee retention. The $\mathrm{R}$ value represents the simple correlation and it indicates a higher degree of correlation if the $\mathrm{R}$ value is high. The $\mathrm{R}^{2}$ value indicates how much of total variance in the dependent variable can be explained by the independent variable. The "ANOVA" table indicates that the regression model predicts the dependent variable significantly well. This will represent by the Sig. value. 


\section{Macrothink}

Table 6. Summary of Regression Analysis

\begin{tabular}{lccccc}
\hline Variable & R & R Square & \multicolumn{2}{c}{ B Value } & Sig. \\
& & & Constant & Average & \\
\hline Company A & & & & & \\
Recruitment \& Selection & 0.063 & 0.004 & 2.858 & 0.067 & 0.518 \\
Performance Management & 0.301 & 0.091 & 1.590 & 0.299 & 0.002 \\
Compensation \& Reward & 0.011 & 0.000 & 3.014 & -0.013 & 0.909 \\
Training \& Development & 0.123 & 0.015 & 2.103 & 0.354 & 0.203 \\
Company B & & & & & \\
Recruitment \& Selection & 0.343 & 0.118 & 2.130 & 0.273 & 0.055 \\
Performance Management & 0.157 & 0.025 & 2.528 & 0.085 & 0.392 \\
Compensation \& Reward & 0.553 & 0.306 & 1.873 & 0.264 & 0.001 \\
Training \& Development & 0.486 & 0.236 & 2.043 & 0.269 & 0.005 \\
Company C & & & & & \\
Recruitment \& Selection & 0.573 & 0.328 & 1.313 & 0.514 & 0.000 \\
Performance Management & 0.482 & 0.232 & 1.639 & 0.364 & 0.000 \\
Compensation \& Reward & 0.588 & 0.346 & 1.221 & 0.425 & 0.000 \\
Training \& Development & 0.622 & 0.387 & 1.245 & 0.546 & 0.000 \\
\hline
\end{tabular}

According to the results of the regression analysis all three companies indicated that there is less impact of HR practices on employee retention.

\subsection{Hypothesis Testing}

Based on the results generated through correlation and regression analyses, the hypothesis built in the second chapter have tested below. If the $\mathrm{p}$ value less than 0.05 ( $\mathrm{p}=<0.05)$ alternative hypothesis (H1) can be accepted where the null hypothesis (H0) is rejected. If the $\mathrm{p}$ value greater than 0.05 ( $\mathrm{p}>0.05)$ alternative hypothesis $(\mathrm{H} 1)$ can be rejected where the null hypothesis (H0) is accepted.

Finally, as a result of hypothesis testing it can be concluded that, though there is a significant relationship between performance management and employee retention, it is only marginally supported as the study found a positive yet weak relationship in Company A. In Company B compensation \& reward and training \& development as well as in company $\mathrm{C}$ all four HR practices are significant and there is a strong positive relationship with employee retention. 


\begin{tabular}{|c|c|c|c|c|c|c|c|c|c|}
\hline \multirow[b]{2}{*}{ Hypothesis } & \multicolumn{3}{|c|}{ Company A } & \multicolumn{3}{|c|}{ Company B } & \multicolumn{3}{|c|}{ Company $\mathrm{C}$} \\
\hline & $\begin{array}{c}\mathbf{P} \\
\text { value }\end{array}$ & $\begin{array}{c}\mathbf{R} \\
\text { value }\end{array}$ & $\begin{array}{c}\text { Accepted } \\
/ \\
\text { Rejected }\end{array}$ & $\begin{array}{c}\mathbf{P} \\
\text { value }\end{array}$ & $\begin{array}{c}\mathbf{R} \\
\text { value }\end{array}$ & $\begin{array}{c}\text { Accepted } \\
\text { / } \\
\text { Rejected }\end{array}$ & $\begin{array}{c}\mathbf{P} \\
\text { value }\end{array}$ & $\begin{array}{c}\mathbf{R} \\
\text { value }\end{array}$ & $\begin{array}{c}\text { Accepted } \\
/ \\
\text { Rejected }\end{array}$ \\
\hline Hypothesis 01 & & & & & & & & & \\
\hline $\begin{array}{l}\mathrm{H}_{0} \text { - There is no } \\
\text { relationship between } \\
\text { recruitment \& selection } \\
\text { and employee retention. } \\
\mathrm{H}_{1}{ }^{-} \text {There is a } \\
\text { relationship between } \\
\text { recruitment \& selection } \\
\text { and employee retention. } \\
\text { Hypothesis } 02\end{array}$ & 0.518 & 0.63 & Rejected & 0.055 & 0.343 & Rejected & 0.000 & 0.587 & $\begin{array}{l}\text { Rejected } \\
\text { Accepted }\end{array}$ \\
\hline $\begin{array}{l}\mathrm{H}_{0} \text { - There is no } \\
\text { relationship between } \\
\text { performance } \\
\text { management and } \\
\text { employee retention. } \\
\mathrm{H}_{1^{-}} \text {There is a } \\
\text { relationship between } \\
\text { performance } \\
\text { management and } \\
\text { employee retention. } \\
\text { Hypothesis } \mathbf{0 3}\end{array}$ & 0.002 & 0.301 & Accepted & 0.392 & 0.157 & Accepted & 0.000 & 0.489 & Rejected \\
\hline $\begin{array}{l}\mathrm{H}_{0} \text { - There is no } \\
\text { relationship between } \\
\text { compensation \& reward } \\
\text { management and } \\
\text { employee retention. } \\
\mathrm{H}_{1} \text { - There is a } \\
\text { relationship between } \\
\text { compensation \& reward } \\
\text { management and } \\
\text { employee retention. } \\
\text { Hypothesis } \mathbf{0 4}\end{array}$ & 0.909 & -0.011 & Rejected & 0.001 & 0.553 & Accepted & 0.000 & 0.588 & Accepted \\
\hline $\begin{array}{l}\mathrm{H}_{0} \text { - There is no } \\
\text { relationship between } \\
\text { training \& development } \\
\text { and employee retention. } \\
\mathrm{H}_{1^{-}} \text {There is a } \\
\text { relationship between } \\
\text { training \& development } \\
\text { and employee retention. }\end{array}$ & 0.203 & 0.123 & Rejected & 0.005 & 0.486 & Accepted & 0.000 & 0.616 & Accepted \\
\hline
\end{tabular}

\section{Conclusion and Recommendations}

\subsection{Conclusion}

The achievement of objectives of the study can summarize accordingly with the research main objective and three sub objectives. 


\subsubsection{The Impact of HR Practices on Employee Retention}

The main objective of the study is to find the impact of HR practices for employee retention. According to the regression analysis conducted in order to find this impact it was revealed that there is a low impact of HR practices for employee retention.

\subsubsection{Organizational HR Practices}

In order to achieve the first sub objective which is aimed at studying HR practices of the organizations interview method was used and analysis was done through "word Cloud".

The results of this indicates that recruitment and selection, training and development, performance management and compensation management were the mainly highlighted HR practices by the HR managers which was the base to select the independent variables for this study.

\subsubsection{Employee retention Level of the Organizations}

In order to measure this second sub objective which is to measure employee retention level of the organization "One Sample T-Test" was used. Science the mean value is less than 3 study indicates that all three companies have low employee retention.

\subsubsection{The Relationship between HR Practices and Employee Retention}

According to the correlation analysis conducted in order to find the relationship between HR practices and employee retention three different results were generated in selected three companies. Company $\mathrm{C}$ indicated that there is a strong, positive and significant relationship, Company A have weak positive relationship with employee retention where compensation and reward have a negative week relationship with the retention while company B only compensation \& reward and training and development have strong, positive and significant relationship with employee retention.

The analysis indicates different relationships in these three selected companies. Though they are in the same sector the relationship between HR practices and the retention differs. These differences may arise due to different policies and procedures used by each which were identified through interviews conducted with HR managers.

The result of this study was there is a low impact of HR practices on employee retention level. This may be due to the limited number of HR practices and dimensions of retention and there may be other factors available which can impact on the employee retention of organizations in BPO sector.

\subsection{Managerial Implications}

The main finding of this study is there is low impact of recruitment \& selection, performance management, compensation \& reward management and training \& development towards employee retention. Therefore, when management wants to maintain good level of employee retention, they should more HR practices other than these practices mentioned above when formulating policies within the organization. 


\subsection{Limitations and Directions for Future Research}

Science this study is focusing of BPO sector in Sri Lanka there were few sources in order to gather related data related to the study. Therefore, this study mainly focused only on three companies due to the problems such as limited access to the management and unwillingness of management to reveals the information on employees due to the confidentiality and also as the study was based on future researches conducted this study only discussed about the HR practices which were highlighted in previous research articles. Moreover, this study was only limited to executive level employees which is also a limitation of the study.

When considering these limitations, this study can recommend to the future researchers that as this study revealed that the HR practices are different from company to company and even from employee level to level within the same company therefore, future studies can be done by,

- taking one employee level of one company and study all the HR practices related to that company or,

- taking all the employee layer of one company and study only one HR practice form the related HR practices of the company.

Thus, it will be able to provide better outcomes which can provide better recommendations for the management to formulate much effective decisions.

\section{References}

Asiedu-Appiah, F., Kontor, E., \& Asamoah, D. (2013). Effect of Human Resource Management Practices on Employee Retention: Perspectives From the Mining Industry in Ghana. International Research Journal of Arts and Social Sciences, 2(2), 30-48.

Atkinson, M. (2012). Developing and Using a Performance Management Framework: A Case Study. Measuring Business Excellence, $16(3), \quad$ 47-56. https://doi.org/10.1108/13683041211257402

Azeez, S. A. (2017). Human Resource Management Practices and Employee Retention: A Review of Literature. Journal of Economics, Management and Trade, 18(2), 1-10. https://doi.org/10.9734/JEMT/2017/32997

Begum, W., \& Mohamed, M. (2016). A Study on HRM Practices and Its Impact on Job Satisfaction and Organization Performance in BPO Sector,Tiruchirappalli. International Journal of Advanced Research in Management (IJARM), 7(3), 1-9.

Bhanot, N., Rao, P., \& Deshmukh, S. (2016). Identifying the Perspectives for Sustainability Enhancement: A Text Mining Approach for a Machining Process. Journal of Advances in Management Research, 13(3), 244-270. https://doi.org/10.1108/JAMR-02-2016-0012

Biason, R. (2014). The Effect of Job Satisfaction to Employee Retention. 1-10. 
Chiekezie, O. M., Emejulu, G., \& Nwanneka, A. (2017). Compensation Management and Employee Retention of Selected Commercial Banks in Anambra State, Nigeria. Archives of Business Research, 115-127. https://doi.org/10.14738/abr.53.2758

Coffey, L. (2013). The Relationship Between Reward Management and Recognition in the Work Place. The National College of Ireland.

Cohen, J. (1968). Multiple Regression as A General Data Analytic System. Psychological Bulletin, 426-443. https://doi.org/10.1037/h0026714

De Silva, M. H., \& Chitraranjan, C. (2018). Factors Affecting on Gaining a Sustainable Competitive Advantage for Sri Lankan Higher Educational Institutes. International Business Research, 106-118. https://doi.org/10.5539/ibr.v11n4p106

El-Kot, G., \& Leat, M. (2008). A Survey of Recruitment and Selection Practices in Egypt. Education, Business and Society: Contemporary Middle Eastern Issues, 1(3), 200-212. https://doi.org/10.1108/17537980810909823

Hsieh, C., \& kleiner, B. (2003). New Development in Executive Compensation. Management Research News, 26(7), 72-78. https://doi.org/10.1108/01409170310783600

Huang, C., \& Kleiner, B. (2005). Managing Compensation in the Financial Service Industry. Management Research News, 28(11/12), 20-31. https://doi.org/10.1108/01409170510785200

Hughes, J. C., \& Rog, E. (2008). Talent Management: A Strategy for Improving Employee Recruitment, Retention and Engagement within Hospitality Organizations. International Jouranal of Contemporary Hospitality Managment, 743-757. https://doi.org/10.1108/09596110810899086

Irshad, M., \& Afridi, F. (2011). Factors Affecting Employee Retention: Evidence from Literature. Abasyn Journal of Social Sciences, 4(2), 307-339.

Jeet, V., \& Sayeeduzzafar, D. (2014). A Study of HRM Practices and Its Impact on Employees Job Satisfaction in Private Sector Banks. International Journal of Advance Research in Computer Science and Management Studies, 2(1), 2321-7782.

Johnson, D. (2005). Business Process Outsourcing: An Exploratory Study. New Orleans: University of New Orleans Theses and Dissertations.

Kim, G. M., \& Won, H. J. (2007). HR BPO Service Models for Small and Medium Enterprises. Business Process Management Journal, 13(5), 694-706. https://doi.org/10.1108/14637150710823165

Krejcie, R., \& Morgan, D. (1970). RCDetermining Sample Size for Research Activities. Educational and Psychological Measurement, 607-610. https://doi.org/10.1177/001316447003000308

Kundu, S. C., \& Lata, K. (2017). Effects of Supportive Work Environment on Employee Retention. International Journal of Organizational Analysis, 25(4), 703-722. https://doi.org/10.1108/IJOA-12-2016-1100 
Lardner, S. (2015). Effective Reward Ensures Effective Engagement. Strategic HR Review, 14(4), 131-134. https://doi.org/10.1108/SHR-06-2015-0050

LIRNEasia. (2006). A Baseline Sector Analysis of The Business Process Outsourcing Industry of Sri Lanka. Colombo.

Mahmood, N., \& Zafar, S. (2016). HRM Practices for Employee Retention: An Analysis of Pakistani Companies. European Journal of Business and Management, 8(30), 96-104.

Marescaux, E., De Winne, S., \& Sels, L. (2012). HR Practices and HRM Outcomes: The Role of Basic Need Satisfaction. Personnel Review, 42(1), 4-27. https://doi.org/10.1108/00483481311285200

Mathimaran, B., \& Kumar, A. A. (2017). Employee Retention Strategies - An Empirical Research. Global Journal of Management and Business Research: E Marketing, 17(1), 17-22.

Olaniyan, D., \& Ojo, L. B. (2008). Staff Training and Development: A Vital Tool for Organizational Effectiveness. European Journal of Scientific Research, 24(3), 326-331.

Osibanjo, A., Abiodun, A., \& Adeniji, A. (2014). Impact of Job Enviroment on Job Satisfaction \& Commitmenet Among Nigerian Nurses. Journal of South African Business Research, 1-11.

Pandita, D., \& Ray, S. (2018). Talent Management and Employee Engagement: A Meta-Analysis of Their Impact on Talent Retention. Industrial and Commercial Training, 185-199. https://doi.org/10.1108/ICT-09-2017-0073

Patro, C. S., \& Raghunath, K. K. (2015). Employee Welfare is the Key: An Insight. International Journal of Business and Administration Research Review, 3(11), 42-47.

Roselius, W., \& Kleiner, B. (2000). How to Hire Employees Effectively. Management Research News, 23(12), 17-23. https://doi.org/10.1108/01409170010781993

Sahoo, C., \& Mishra, S. (2012). Performance Management Benefits Organizations and Their Employees. Human Resource Management International Digest, 20(6), 3-5. https://doi.org/10.1108/09670731211260771

Saunders, M., Lewis, P., \& Thornhill, A. (2009). Research Methods for Business Management Students (5th ed.). New York: Pearson Education Limited.

Sekaran, U. (2003). Research Methods for Business: A Skill Building Approach (4th ed.). John Wiley \& Sons, Inc.

Silva, H., Udawatta, L., \& Nanayakkara, V. (2011). A Study of IT/BPO Industry and Factors Influencing Their Performance. SAITM Research Symposium on Engineering Advancements, 5(1), 93-96.

SLASSCOM. (2014). Sri Lanka IT/BPM Industry Review. Colombo: SLASSCOM Publication. 


\section{Macrothink}

International Journal of Human Resource Studies

ISSN 2162-3058 2019, Vol. 9, No. 1

Wickramasinghe, V., \& Kumara, S. (2010). Work-related Attitudes of Employees In The Emerging ITES-BPO Sector of Sri Lanka. Strategic Outsourcing: An International Journal, 3(1), 20-32. https://doi.org/10.1108/17538291011023052

\section{Copyright Disclaimer}

Copyright for this article is retained by the author(s), with first publication rights granted to the journal.

This is an open-access article distributed under the terms and conditions of the Creative Commons Attribution license (http://creativecommons.org/licenses/by/4.0/). 